\title{
The Use of the Remand Provisions in the 1983 Mental Health Act
}

Adrian Ground, University Lecturer in Forensic Psychiatry, Institute of Criminology, West Road, Cambridge

The 1983 Mental Health Act introduced new powers for courts to remand mentally disordered defendants to hospital. The provisions came into operation in October 1984 , and were preceded by a Ministerial statement that the new arrangements were becoming available because the Government believed,

“... the mentally ill should be treated in hospital, wherever possible, and they did not wish the courts to have to send sick people to prison." (Hansard: Written Answer, 23 October 1984)

Within the prison medical service there was a similar hope that the new powers would achieve a significant reduction in the number of mentally disordered people held in prison on remand. To what extent has this hope been realised?

The study

Home Office and DHSS statistics on medical remands, reports by prison medical officers and admissions to hospital under the criminal provisions of the Mental Health Act were examined for the years 1983 and 1985 . This enabled a comparison to be made of practice during the calendar years immediately before and after the introduction of the new powers.

The last full year before the introduction of the new provisions was 1983. In that year the number of psychiatric reports by prison medical officers on defendants remanded in custody was 8762 , (i.e. $0.8 \%$ of all those proceeded against in the courts, excluding summary motoring offences). In 766 of these cases (8.7\%) hospital orders were eventually made by the courts at the sentencing stage. ${ }^{1,2}$ The total number of hospital order admissions in 1983 was $845 .^{3}$ The numbers indicate that the great majority of hospital orders made in 1983 resulted from recommendations made by prison medical officers, and relatively few arose from assessments done outside the penal system, in the NHS (Fig. 1).

The new powers which came into force in October 1984 enabled courts to remand mentally disordered defendants to hospital instead of prison. Defendants with any category of mental disorder could be remanded for a report (Section 35 ), and the mentally ill and severely mentally impaired could be remanded for treatment (Section 36). A further provision, the interim hospital order (Section 38), became available for cases where the court considered a hospital order might be an appropriate eventual disposal.

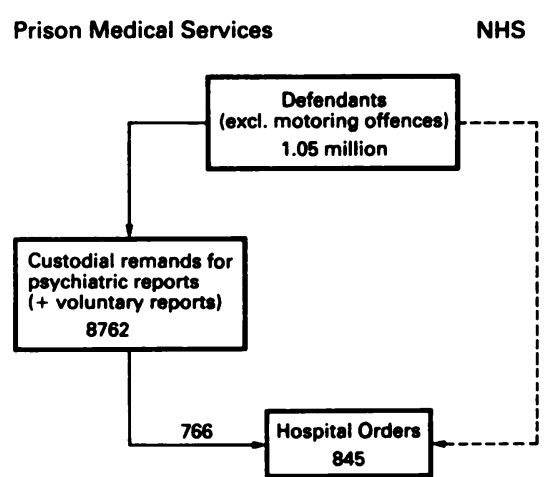

FIG. 1. Custodial Remands for Psychiatric Reports and Hospital Order Admissions in 1983.

The first full year of operation of these new powers was 1985 (Fig. 2). In that year the number of defendants remanded in custody on whom psychiatric reports were prepared was 8762 (calculated on a pro rata basis). As in 1983 they constituted $0.8 \%$ of all defendants proceeded against in the courts (excluding motoring offences)..$^{4.5 .6}$ The number of hospital orders resulting from prison medical officers' reports was 656 (also calculated on a pro-rata basis), i.e. $8.6 \%$ of the psychiatric remands. The total number of hospital order admissions in 1985 was 880 (Home Office: unpublished statistics).

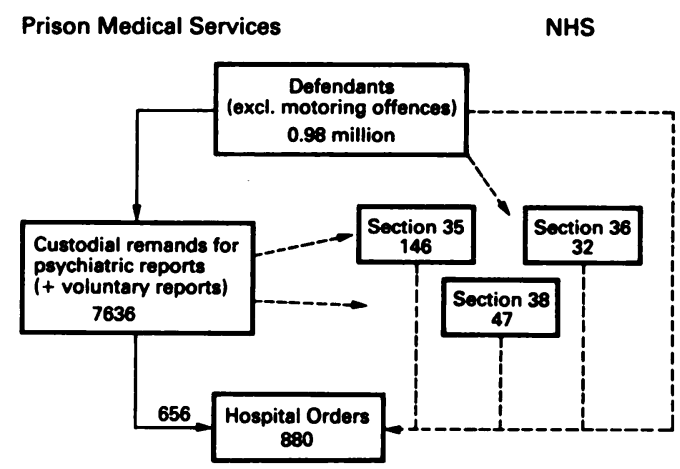

Fig. 2. Custodial Remands for Psychiatric Reports and Hospital Order Admissions in 1985. 
Admissions under the new remand sections ( 35 and 36 ) to all hospitals (including special hospitals) totalled 178 in 1985. There were a further 47 admissions under interim hospital orders (Section 38), (of whom three were in the category 'psychopathic disorder' and all the remainder were in the category 'mental illness'). ' It is not clear how many of these cases eventually received hospital orders, but at most they could have contributed no more than a quarter of the total number of hospital orders made in that year.

Comment

During the first full year of operation the contribution made by this new legal avenue for psychiatric remands was numerically small, and the House of Commons Social Services Committee, in its recent report on the Prison Medical Service ${ }^{8}$ noted that, “. . . to date this power has not been used to its full potential" (para. 56).

However, the above figures suggest that the new provisions may have had some effect in increasing the number of hospital orders made. The proportion of prison medical officers' reports resulting in hospital orders remained unchanged $(8.6 \%$ in 1983 and $8.7 \%$ in 1985$)$; but when the new provisions are taken into account the total number of hospital orders made shows an increase. Using psychiatric custodial remands as a baseline, the total number of hospital orders in 1983 was $9.6 \%$, but in 1985 it showed a statistically significant rise to $11.5 \%\left(\chi^{2}=12.4 \mathrm{df}=1 \quad P<0.001\right)$. Recommendations by prison medical officers accounted for $90.7 \%$ of the hospital order admissions in 1983 , but this fell to $74.5 \%$ of the admissions in $1985\left(\chi^{2}=7.4 \mathrm{df}=1\right.$ $P<0.01)$. There appears to have been a small but significant shift towards the NHS as the source of reports for hospital orders.

Clearly, no conclusions can be drawn about the likely future use of these provisions on the basis of the first year's figures, and it is to be expected that the number of orders made under the new Sections will increase as hospitals and courts become more familiar with them. The figures available to date give some cause for encouragement in showing that the new powers may have led to more hospital orders being made, but the numbers are very small, and there remains the question of whether the underlying intention of the new powers, namely to divert substantial numbers of remanded mentally disordered defendants from prison to hospital, is likely to be realised. The above statistics emphasise that the bulk of the psychiatric screening and assessment of people requiring custodial remands, and their selection for hospital orders, continues to be done in the penal system rather than in the NHS. Moreover, the Prison Medical Association, in its evidence to the Social Services Committee (1986) stated the view that local prisons,

"... act in effect as acute psychiatric assessment centres for those whose behaviour has brought them into conflict with the law, and the use of the 'remand to hospital' facilities introduced in the 1983 Mental Health Act cannot be widely applied until there has been a period of assessment in conditions which ensure the safety of both the defendant and the public." (Minutes of Evidence, p. 32).

The new provisions are to be welcomed for the flexibility they allow in assessing and treating mentally disordered defendants, but whether they can provide an alternative to prison for the majority of psychiatric custodial remands is less certain. The policy of diverting the mentally disordered from prison to hospital appears laudable in principle, but can it really be translated into practice?

\section{ACKNOWLEDGEMENTS}

I am grateful to Mr D. M. Bailey and Mr M. Lewis of the DHSS, and to Mr G. L. Thomas of the Home Office, for help in obtaining admission statistics; and to Dr G. Robertson, Institute of Psychiatry, for advice and comments on the text.

REFERENCES

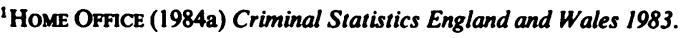
(Cmnd. 9349). London: HMSO.

2 - (1984b) Report on the Work of the Prison Department 1983. (Cmnd. 9306). London: HMSO.

3 - (1985a) Statistical Bulletin 4/85: Statistics of Mentally Disordered Offenders, England and Wales 1983. London: Home Office Statistical Department.

4 (1985b) Report on the Work of the Prison Department 1984/85. (Cmnd. 9699). London: HMSO.

5_- (1986a) Criminal Statistics England and Wales $1985 .(\mathrm{Cm} .10)$. London: HMSO.

6 - (1986b) Report on the Work of the Prison Department 1985/86. (Cm. 11). London: HMSO.

'Department of Health and Social Security (1987) Mental illness and mental handicap hospitals and units in England: Legal status statistics 1982-1985. Statistical Bulletin 2/87. London: DHSS.

${ }^{8}$ House OF Commons (1986) Third Report from the Social Services Committee Session 1985-86 Prison Medical Service Vols. I and II. London: HMSO. 